\title{
WestVirginiaUniversity
}

THE RESEARCH REPOSITORY @ WVU

Graduate Theses, Dissertations, and Problem Reports

2021

\section{Jurors' Perceptions of False Confessions}

Madison G. Gallimore

West Virginia University, mgg0016@mix.wvu.edu

Follow this and additional works at: https://researchrepository.wvu.edu/etd

Part of the Clinical Psychology Commons, Cognitive Psychology Commons, Criminal Law Commons, and the Law and Psychology Commons

\section{Recommended Citation}

Gallimore, Madison G., "Jurors' Perceptions of False Confessions" (2021). Graduate Theses, Dissertations, and Problem Reports. 10200.

https://researchrepository.wvu.edu/etd/10200

This Thesis is protected by copyright and/or related rights. It has been brought to you by the The Research Repository @ WVU with permission from the rights-holder(s). You are free to use this Thesis in any way that is permitted by the copyright and related rights legislation that applies to your use. For other uses you must obtain permission from the rights-holder(s) directly, unless additional rights are indicated by a Creative Commons license in the record and/ or on the work itself. This Thesis has been accepted for inclusion in WVU Graduate Theses, Dissertations, and Problem Reports collection by an authorized administrator of The Research Repository @ WVU. For more information, please contact researchrepository@mail.wvu.edu. 


\section{Jurors' Perceptions of False Confessions}

Madison Gallimore

Thesis submitted

to the Eberly College of Arts and Sciences

at West Virginia University

in partial fulfillment of the requirements for the degree of

Masters of Science

in Psychology

Elisa Krackow, Ph.D., Chair

Amy Fiske, Ph.D.

Constance Toffle, Ph.D.

Department of Psychology

Morgantown, West Virginia

2021

Keywords: Jurors' perceptions, false confessions

Copyright 2021 Madison G. Gallimore 


\section{Abstract \\ Jurors' Perceptions of False Confessions Madison G. Gallimore}

This study examined the effect of mock jurors' perceptions of a defendant's false confession vs. no confession (false confession presence), coercive interrogation techniques vs. panic-escape (false confession reason), and expert witness testimony vs. defendant explanation vs. expert witness testimony plus defendant explanation for his false confession (source). The four hypotheses and one research question pertained to main effects and interaction effects of false confession presence, false confession reason, and source (separately) and expert witness conditions combined on five outcome variables. Outcome variables were defendant's guilt, trustworthiness, suggestibility, susceptibility to external influences, and juror's likelihood of changing their verdict. Using Amazon Mechanical Turk (MTurk), mock jurors $(N=415)$ were randomly assigned to one of twelve conditions, in which they read a murder trial scenario and answered questions regarding the outcome variables. Main effects of false confession were found within the defendant's perceived guilt, trustworthiness, and suggestibility. Main effects of source were also found, such that the defendant's perceived guilt, suggestibility, and susceptibility to external influences were significant, as was to jurors' likelihood of changing their verdict (guilty/not guilty) but follow-up analyses yielded an inconsistent pattern. Expert witness testimony reduced perceptions of guilt and suggestibility, and decreased jurors' openness to changing their verdict. Numerous False Confession x Reason interactions emerged pertaining to the defendant's perceived guilt, trustworthiness, and suggestibility, as well as the jurors' likelihood of changing their verdict (guilty/not guilty). A series of planned contrasts comparing the false confession/coercive interrogation/expert witness vs. the false confession/panic- 


\section{JURORS' PERCEPTIONS OF FALSE CONFESSIONS}

escape/expert witness conditions; the false confession/coercive interrogation/defendant vs. false confession/panic-escape/defendant condition; and the false confession/coercive interrogation/expert witness + defendant vs. false confession/panic-escape/expert witness + defendant showed no significant differences in jurors' perceptions of the defendant's guilt. Keywords: jurors' perceptions, false confessions 


\section{Table of Contents}



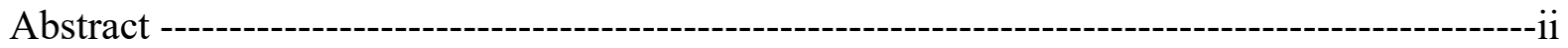

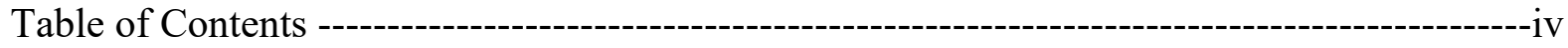

Introduction ---------------------------------------------------------------------------------------------------------1

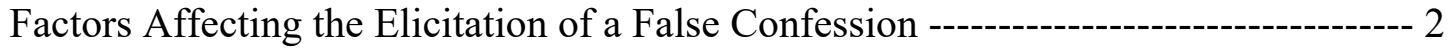
Individual Characteristics, Bodily States, and False Confessions ----------------2

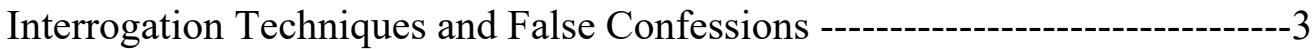

Jurors' Perceptions of Confession Eliciting Techniques ----------------------------------7

Jurors' Perceptions of Expert Witness Testimony in False Confession Cases ---------8

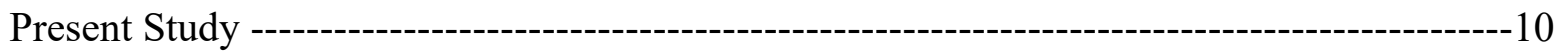

Hypotheses and Research Question ------------------------------------------------------------------12

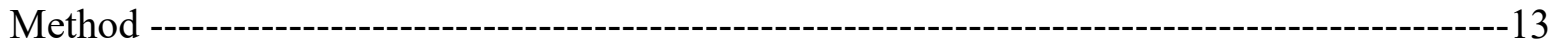

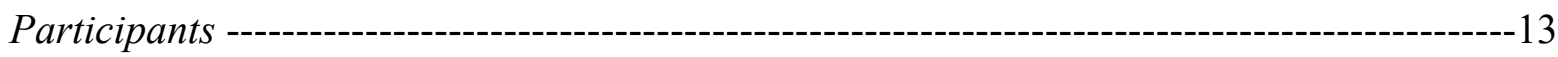

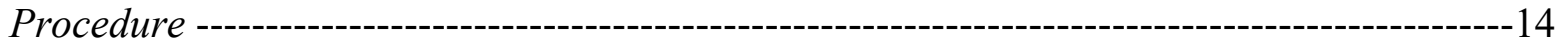

Results -----------------------------------------------------------------------------------------------------------17

Defendant Trustworthiness --------------------------------------------------------------------------18

Defendant Guilt ----------------------------------------------------------------------------------------19

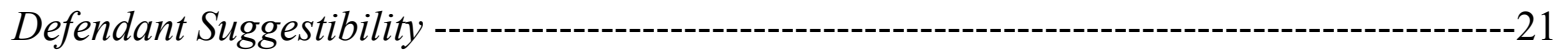

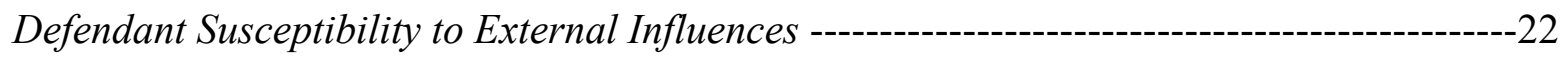

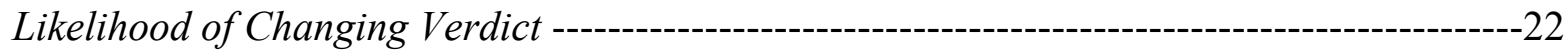

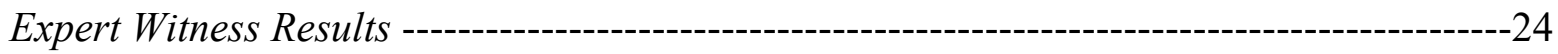

Discussion -------------------------------------------------------------------------------------------------------24

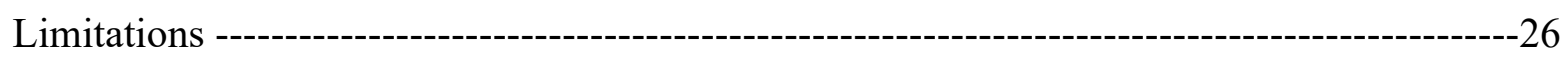

Future Directions ---------------------------------------------------------------------------------------------27

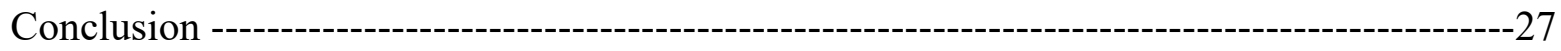

References ------------------------------------------------------------------------------------------------------29

Table 1 -----------------------------------------------------------------------------------------------------------34

Table 2 -----------------------------------------------------------------------------------------------------35

Table 3 ----------------------------------------------------------------------------------------------------------36

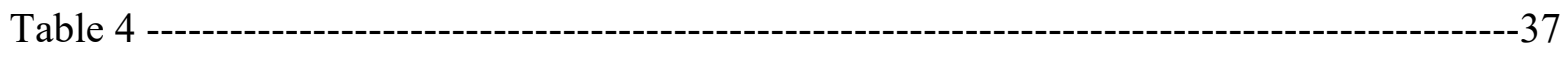

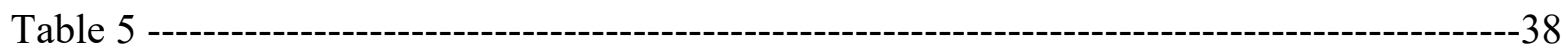

Table 6 ------------------------------------------------------------------------------------------------------------39

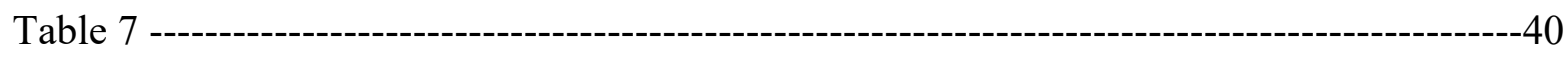

Table 8 ---------------------------------------------------------------------------------------------------41 


\section{Introduction}

The use of DNA evidence has become the gold standard for determining who committed a crime (West \& Meterko, 2016). If the DNA collected from a crime scene does not match the suspect who confessed, the confession is often deemed false (Lynch, 2008). It is unknown how many people have been wrongfully convicted due to false confessions. However, in $27 \%$ of all cases exonerated through DNA evidence a false confession was given (West \& Meterko, 2016).

Several studies have examined the methods that jurors perceive to lead to false confessions. A survey was administered to 116 jury eligible participants to determine their beliefs about false confessions (Henkel, Coffman, \& Dailey, 2008). Henkel et al. (2008) found that interrogation characteristics, such as torture, were reported to be the most likely to increase false confessions. Other coercive interrogation techniques, such as lengthy interrogations lasting for multiple hours, minimization (i.e., decreasing the seriousness of the crime), maximization (i.e., increasing the seriousness of the crime), and pretending to befriend the suspect (e.g., interrogator pretends to care about the suspect to get the suspect to open up about the crime) were rated moderate to high in how often they are thought to be used by interrogators. Suspects who are young, have intellectual deficits, and have been diagnosed with a mental illness were thought to be more susceptible to giving a false confession. However, participants also reported that confessions are a strong sign of guilt and believed that they themselves would not falsely confess to a crime.

In a second investigation, Costanzo, Shaked-Schroer, and Vinson (2010) had all participants (461 jury eligible people identified by census data) first answer fifteen questions on a ten-point Likert-type scale. Questions included the ability to distinguish between true and false confessions (e.g., "Interrogators' ability to detect lies improves with experience") which was 
endorsed by $60 \%$ of jurors (Costanzo et al., 2010, p. 239). Other beliefs about false confessions included "If interrogated, I would falsely confess to a serious crime" (agreed with by 3.9\% of jurors), and the rates of false confessions, "What percentage of confessions in murder cases are false?” (jurors reported 22.3\%) (Costanzo et al., 2010, p. 239). The use of minimization and expert witness testimony were supported by jurors (24\% and 67\%, respectively) (Costanzo et al., 2010). However, most of the participants did not approve of interrogators lying to suspects about polygraphs, DNA, or non-existent eyewitnesses, nor did jurors view threats or promises of leniency as permissible (Costanzo et al., 2010).

An experimental study demonstrated that both true and false confessions are believed more often than not ( $88 \%$ of the time) by individuals who are jury eligible (Levin, Kim, \& Blair, 2010). Participants also erroneously believed that people can distinguish between true and false confessions and had confidence in their ability to do so (Honts, Kassin, \& Craig, 2014; Kassin, Meissner, \& Norwick, 2005). Therefore, an important area of study is how false confessions actually come to be elicited by interrogators.

\section{Factors Affecting the Elicitation of a False Confession}

\section{Individual Characteristics, Bodily States, and False Confessions}

Drizin and Leo (2005) collected data from 125 real false confessions in which people often falsely confessed to a murder. Of those false confessions that went to criminal trial, $86 \%$ of people were convicted. Thirty percent of false confessors were 25-to-39-years-old, and 27 percent of false confessors were 18-to-24-years-old. Interrogations were often lengthy, with 39\% lasting 12-24 hours and 34\% lasting 6-12 hours. Factors increasing susceptibility to falsely confessing are as follows: the presence of two or more interrogators; lengthy interrogations; use of deception and individual characteristics (i.e., being young in age; being trusting; having a poor 
memory; being submissive; having low self-control; being of limited intelligence; having a developmental disability; and having a mental illness, including but not limited to, ADHD, antisocial personality disorder, and having an anxious predisposition) (Conti, 1999; Gudjonsson, 1990; Gudjonsson et al., 2012; Kassin, 2010; Klaver, 2008). Being innocent is another risk factor given that wrongly convicted false confessors have reported thinking that the evidence would clear them and so there was no harm in telling investigators what they wanted to hear to end the interrogation (Kassin, 2010). Bodily states, such as sleep deprivation have been shown to affect the decisions that people make, including the decision to provide a false confession (Frenda, Berkowitz, Loftus, \& Fenn, 2015).

In addition to individual characteristics and bodily states, certain interrogation techniques can increase the likelihood of a false confession. These will now be discussed.

\section{Interrogation Techniques and False Confessions}

Various techniques are used by interrogators during police interviews to obtain a confession (Perillo \& Kassin, 2010). A specific strategy is bluffing (i.e., deceiving suspects by hinting that incriminating evidence can be or has been obtained). False evidence may make the interviewee think that their fate is sealed so the best that they can hope for is leniency if they confess (Kassin, 2010).

Perillo and Kassin (2010) examined whether using a bluff increases the rates of false confessions. Participants were randomly assigned to one of five conditions, which varied in the confederate's statement in the presence of the participant and the inclusion of a bluff statement (i.e., interrogator could prove the participant's guilt by reviewing the participant's keystrokes). Each condition and the confession rate will now be reviewed. There was a confederate who either said that they saw the participant press the ALT key (Condition 1, 78.6\%), did not see the 
participant press the ALT key (Condition 2, 35.7\%), or were unsure as to whether the participant pressed the ALT key (i.e., control group Condition 3, 26.7\%). In Condition 4 (86.7\%), the interrogator used a bluff on its own to verbally indicate that he could prove the participant's guilt by reviewing the participant's keystrokes. In Condition $5(79.9 \%)$, the interrogator used the same bluff as Condition 4 plus the confederate reported that they saw the participant press the ALT key. These results show that using the bluff technique (Conditions 4 and 5) greatly increased people's likelihood of falsely confessing.

Perillo and Kassin (2010) completed a second study in which they randomly assigned participants to either a bluff technique only or control condition to determine the effect of a bluff on its own. The computer crash paradigm was used again, but those who confessed were interviewed afterward to collect data on why they confessed and if they believed that they were guilty. In the bluff condition, $74 \%$ falsely confessed, compared to $47 \%$ in the control condition. Of those who confessed in the bluff condition, $75 \%$ reported that they confessed because of the deception.

In a third study, a second scenario was developed based on a similar paradigm (Russano, et al., 2005) that included a control group to determine if a similar rate of false confessions would occur as with the original cheating paradigm. Fifty percent of those who experienced the bluff technique confessed, whereas no one in the no-bluff control group confessed. This percentage was consistent with the experimental condition's rate in the second study $(57.9 \%)$, as opposed to the even higher rates of confession in the first study.

In summary, in two of the three previously described studies, bluff techniques elicited confessions from participants approximately $50 \%$ of the time (Perillo \& Kassin, 2005, 2010). 
Minimization (i.e., downplaying the crime that was committed), is another common technique used by interrogators to get suspects to confess. In addition, deals are often offered to persuade suspects to confess based on the possibility of obtaining a lighter punishment. Despite their frequency, critics doubt their coercive influence in the lab, due to participants not having anything at stake (Russano, et al., 2005).

Russano et al. (2005) used a 2 (guilty vs. innocent) x 2 (minimization vs. no minimization) x 2 (deal vs. no deal) design to examine whether differences exist between true and false confessions when coercive interrogation techniques are used. A participant and confederate were left alone in a room after being told to answer questions without working together. In the guilty condition, the confederate asked the participant for help on an individual item, but in the innocent condition, the confederate did not ask for help. Guilty condition participants made their own decision about whether or not to help the confederate. Participants were accused by the interrogator of working with another person based on getting the same questions wrong as the confederate. The interrogator used minimizing phrases such as "I'm sure you didn't realize what a big deal it was" (Russano et al., 2005, p. 483). If the participant did not take the deal, they would not receive their research credit and would have to face another unknown consequence. If the participant refused or seemed hesitant, the interrogator repeated the interrogation techniques specific to the experimental condition until the confession was signed or 3 more times. False confessions ranged from $6 \%$ with no interrogation tactic, to $14 \%$ when a deal was offered, to $18 \%$ when minimization was used, to $43 \%$ when a deal plus minimization was used.

Using a similar paradigm as above, Narchet, Meissner, and Russano (2011) designed a study to see if interrogators' guilt biases would increase the rates of false confessions. 
Interrogator bias regarding the suspect's guilt was manipulated within the study via another researcher making comments to the interrogator about the defendant's guilt (i.e., they cheated by obtaining help from the confederate on a questionnaire that they were told to fill out themselves). The biasing researcher stated that the suspect was guilty, innocent, or that they were unsure of the suspect's guilt (i.e., control group). The bias manipulation occurred after the experimenter collected the questionnaires, at which time they became interrogators. Interrogators used any of the minimization or maximization techniques that they learned during their 5-week training to obtain a true confession. Participants were interrogated for up to 15 minutes and then asked one time to sign a confession at the end of the interrogation. If the participant refused to sign the confession, they were informed that the interrogator would have to call the principal investigator to determine how to proceed. False confessions were lowest $(20 \%)$ when the interrogator had no bias, but rose to $26 \%$ under innocent bias, and increased to $47 \%$ when the interrogator thought that the participant was guilty. Participant false confession rates increased with the use of interrogation tactics. The false confession base rate was $3 \%$ when no techniques were used, followed by $11 \%$ when maximization was used, $22 \%$ when minimization was used, and $43 \%$ when minimization plus maximization were used.

To summarize, bluffs, false evidence, minimization, maximization, and offering a deal are interrogation techniques that are often used by interrogators and their frequency increases when an interrogator believes that the suspect is guilty (Narchet, et al., 2011). This is a problem because these interrogation techniques have been shown to increase the likelihood of confessions due to pressure on the suspect to confess (Perillo \& Kassin, 2010; Russano et al. 2005; Narchet, et al. 2011). 
Although data shows that particular interrogation techniques increase the likelihood of a false confession, it is also important to examine the way that jurors perceive these techniques.

\section{Jurors' Perceptions of Confession Eliciting Techniques}

As discussed, confessions are an influential piece of evidence for jurors in a criminal trial. Researchers (Kassin \& Sukel, 1997) were interested in the weight that a confession can have on a determination of guilt. Participants were given a transcript of a murder trial with circumstantial evidence and a confession. The suspect within the low-pressure interrogation blurted out their confession despite no coercive interviewing techniques being used by the interrogator. The high-pressure interrogation consisted of an interrogator flaunting a weapon and making the suspect physically uncomfortable via handcuffs. In the admissible condition, the judge ruled that the confession could be used as evidence, compared to the inadmissible condition in which the jurors learned of a confession, but the judge ruled that the confession was inadmissible. A confession may be inadmissible if its reliability is questionable. An inadmissible condition was added to determine whether jurors who were instructed to disregard a confession are able to do so when deciding upon a verdict on guilt. The confession was elicited under either a low-or high-pressure interrogation and the confession was either admissible or inadmissible in court. A no confession control group was compared to the 4 experimental conditions. Jurors were asked to rate whether they thought that the confession was voluntary, to decide on a verdict on guilt, to rate their confidence in that verdict, and to indicate whether or not they thought the confession influenced their verdict. Jurors rated the confession as more voluntary when it occurred under low pressure circumstances compared to high pressure circumstances. However, conviction rates between the high- and low-pressure interrogation conditions did not significantly differ. These findings highlight the incongruence between jurors' beliefs that 
interrogation techniques can be coercive, and their decisions regarding guilt when a confession exists. However, jurors may perceive interrogation techniques and confession evidence differently when an expert witness testifies.

\section{Jurors' Perceptions of Expert Witness Testimony in False Confession Cases}

An experimental study by Blandón-Gitlin, Sperry, and Leo (2009) examined whether expert witness testimony would help jurors evaluate a criminal case. Within this study, the murder trial transcript was divided into two parts, pre-and post-expert testimony. Jurors read a summary of the events from the defendant being interrogated (e.g., after a night of not sleeping or eating), being persuaded to take a polygraph test, and retracting his confession shortly after giving it. Jurors were then given a questionnaire for the first time in the repeated-measures design to assess juror outcome variables (e.g., ratings of the coerciveness of interrogation techniques and their verdict regarding the defendant's guilt). Jurors then read the second part of the trial transcript. The expert witness testified about research on common coercive interrogation strategies including maximization, minimization, bluffing and false evidence. The expert then pointed out interrogation techniques that were concerning from the interrogation in question and that the use of these techniques could have led to a false confession. Jurors were then given another questionnaire, with some of the same questions as before. Higher rates of coercion were reported for all interrogation techniques after expert testimony.

Woody and Forrest (2009) examined whether jurors were affected by expert testimony about false evidence ploys in a murder case. They used a 4 (false evidence ploy type) x 2 (expert witness testimony present vs. not present) design. The false evidence ploys were a bloody fingerprint that was found at the crime scene, an eyewitness that placed the suspect at the scene of the crime, or an interrogator that stated that the suspect's face changed when seeing evidence photos. 
One control group was included that did not receive a false evidence ploy. All jurors answered questions regarding the defendant's guilt, an appropriate sentence for punishment, and the false evidence's (if applicable) degree of deceptiveness and coerciveness. There were no significant differences between the three false evidence conditions on ratings of defendant guilt, deception, or coercion, but each differed in the expected direction when compared to the control condition. Convictions and recommended sentences were not impacted by false evidence, but conviction rates were lower and recommended sentences were shorter when the expert witness testified.

Woestehoff and Meissener (2016) designed a study manipulating the level of coercion and type of expert testimony to determine if adding expert testimony would decrease convictions. Each coercion level included the previous level's tactics. Under low pressure, the defendant was encouraged to tell the truth; under medium pressure, the interrogator used minimization plus a false evidence ploy (e.g., DNA evidence); and under high pressure, the interrogator threatened the death penalty and physically intimidated the suspect. Participants read transcripts with general expert testimony on false confessions (e.g., false confession risk factors), case specific expert testimony on false confessions (i.e., expert testimony specific to this case on false confessions) or no expert testimony. Participants in the expert testimony conditions were able to identify more false confession factors than participants in the no expert testimony conditions, but their verdicts and opinions on guilt were no different. Participants in the lowpressure condition were significantly more likely to convict than those in the medium and high conditions, as well as the no confession control group, but there were no conviction rate differences between the medium and high-pressure conditions. This suggests that jurors are able to distinguish to some degree between various amounts of coercion. 
Shifton (2019, Study 2) used a 2 (number of interrogators) x 2 (interrogation length) x 2 (suspect wakefulness) design, which yielded 8 conditions (no expert witness testimony). A $9^{\text {th }}$ condition was added that included expert witness testimony to examine the effects of expert witness testimony on jurors' perceptions of evidence strength. All participants read a criminal trial summary that included evidence (i.e, false confession, eyewitness testimony, and blood typing). The number of interrogators was either 1 or 3 ; the interrogation was either 1 or 16 hours long; and the suspect's wakefulness was described as either just waking up or just getting off an 8-hour work shift. The expert witness testified on how the defendant's fatigue, the number of interrogators, and the length of interrogation may increase the likelihood of a false confession. Interestingly, mock jurors rated the confession as a stronger piece of guilty evidence when expert testimony was included. The best predictor of a guilty verdict was the presence of a confession. A 1-hour interrogation and a rested suspect also predicted a guilty verdict.

In summary, results that examined the effect of expert testimony on verdicts have been inconsistent. Findings suggest that when an expert testifies about false confessions, jurors recognize coercive interviewing techniques (e.g., false evidence) (Blandón-Gitlin, et al., 2009; Woody \& Forrest, 2009; Woestehoff \& Meissener, 2016) and convict less often (Woestehoff \& Meissener, 2016; Shifton, 2019). However, some findings do not show false confession expert testimony as having a direct effect on convictions. In Woestehoff and Meissener's (2016) study, convictions were predicted by pressure level, but not by expert witness presence. Furthermore, in Shifton (2019) the presence of an expert witness increased the perceived strength of the confession evidence. The presence of expert witness testimony was however found to reduce sentencing recommendations (Woody \& Forrest, 2009).

\section{The Present Study}


Although previous research has examined jurors' perceptions of coercive interrogation techniques and coercive interrogations can be conceptualized as a reason for a false confession, no studies have compared jurors' perceptions of an external reason for false confession (i.e., coercive interrogation techniques) to an internal reason for false confession (i.e., feeling a panic attack coming on so the suspect feels the need to escape the room). Therefore, the current study asked the following questions: Are there differences in jurors' perceptions of a false confession when external reasons for a confession (coercive interrogation) are compared to internal reasons (desire to escape the interrogation room due to anxiety)? Does it make a difference in jurors' perceptions if an expert witness testifies about how coercive interrogation techniques can lead to false confessions or how panic disorder can lead a person to confess due to wanting to escape the interrogation room? To answer questions about the potential impact of an expert witness versus no expert witness on the outcome variables, the two expert witness conditions were combined. To answer questions about the potential impact of source, jurors heard the defendant's stated reason for falsely confessing plus the expert witness's testimony confirming that, according to the research, the defendant's stated reason can in fact lead to a false confession or heard only the defendant's stated reason or only the expert witness's testimony.

Finally, the study included parallel no false confession conditions as controls to determine whether the results remain the same as in the false confession conditions (e.g., Do jurors recognize coercive interrogation techniques when the techniques do not result in a false confession). The variables that were manipulated were the presence of a false confession by the defendant, the reason for the false confession, and the confession reason notification source. These variables produced 12 conditions in a 2 (false confession: present vs. absent) x 2 (reason: coercive interrogation vs. panic-escape) x 3 (source: expert witness vs. defendant vs. expert 
witness plus defendant) between-subjects design. Outcome variables were the perceptions of the defendant's trustworthiness, guilt, suggestibility, and susceptibility to external influences (e.g., memory report affected by others). The likelihood of jurors changing their mind on their verdict of guilt was an additional outcome variable.

\section{Hypotheses and Research Questions}

Hypothesis 1: The defendant's perceived guilt will be lower, suggestibility will be higher, and susceptibility to external influences will be higher in the False Confession conditions compared to the No False Confession conditions (i.e., main effect of false confession). This hypothesis was based on the findings by Woody and Forrest (2009). There was no hypothesis made on jurors' perceived likelihood of changing their verdict (from guilty or not guilty to the opposite verdict) given than no studies have included this variable.

Hypothesis 2: In the Coercive Interrogation groups, there will be higher perceived guilt than in the Panic-escape conditions, higher suggestibility, higher susceptibility to external influences, and greater likelihood of jurors changing their verdict from guilty to not-guilty vice versa (i.e., main effect of reason). This hypothesis was based on the findings by Woody and Forrest (2009). There was no hypothesis made on defendant's perceived trustworthiness given that the previous studies of false confessions cited herein have not included this variable.

Hypothesis 3: In the False Confession present conditions (combined Expert Witness + Defendant and expert only conditions) guilt ratings will be reduced when an expert witness testifies about the coerciveness of the interrogation, compared to when an expert witness does not testify about the coerciveness of the interrogation (i.e., Defendant only condition). In previous studies, mock jurors were less likely to view the defendant as guilty when an expert witness testified compared 
to when an expert witness did not testify (e.g., Woody \& Forrest, 2009; Blandón-Gitlin et al., 2009).

Hypothesis 4: In the False Confession present conditions, per planned contrasts, the Coercive Interrogation condition will yield higher guilt ratings than the Panic-escape condition within the same source (i.e., FC/CI/ExpW vs. FC/PE/ExpW; FC/CI/D vs. FC/PE/D; and FC/CI/ExpW+D vs. FC/PE/ExpW+D). In Woody and Forrest (2009), participants recognized coercive interrogating and the current study includes details of a coercive interrogation within the coercive interrogation scenarios. Furthermore, a panic attack (i.e, Panic-Escape condition) is an unrecognizable reason for falsely confessing that is unknown to others unless stated by the defendant.

Research Question 1: Will there be any interaction effects between the confession presence, the reason, and the source on each of the five outcome variables (i.e., trustworthiness, guilt, suggestibility, susceptibility to external influences, and likelihood of changing their verdict)?

\section{METHOD}

\section{Participants}

Participants $(N=415)$ were recruited through Amazon Mechanical Turk (MTurk). The inclusion criteria of the study were being 18 years old and older, as well as living in the United States. The number of participants per condition ranged from 26 to 44, which is consistent with previous jurors' perception studies (e.g., Bottoms \& Goodman, 1994; Lynch, Wasarhaley, Golding, \& Simcic, 2013). Table 7 includes the number of participants per condition. An additional 286 participants were removed for responding incorrectly to attention questions regarding the trial scenario. The average age of the participants in the current study was 39.4 and the age range was 19 -to-77-years-old. The sample was $55.4 \%$ male, $43.9 \%$ female, and $0.7 \%$ 
non-binary. The sample identified as White (75\%), Asian/Asian American (10\%), Black/African American (9\%), Hispanic/Latino(a) (6\%), Biracial (1.4\%), other (0.7\%), American Indian/Indigenous (0.4\%), and Pacific Islander (0.2\%).

\section{Procedure}

The procedure of this study was generally the same as Tessier and Krackow (2013), Krackow and Longo (2016), as well as Krackow (2018). After viewing the study description on MTurk, participants enrolled themselves in the study via consenting to participate. They were then randomly assigned to read one of twelve scenarios reflective of the experimental conditions (Krackow, 2020). The scenarios pertained to a 25-year-old male on trial for murder. All scenarios described a couple that went on a camping trip, during which the girlfriend died and was found in the lake. The boyfriend (i.e., suspect) was then interrogated by the police on two separate occasions. The suspect's age ( 25 years old) was supported by the findings of Drizin and Leo (2005) showing that young adults are more susceptible to false confessions.

Additional scenario details varied between conditions based on false confession presence, the reason for the false confession, and the source. When a false confession was present, the defendant was described as confessing during the second interrogation. The scenario did not state whether the confession was true or false, but it was in fact false. The reason for the false confession was either due to the interrogator using coercive interrogation techniques or because the defendant felt the need to escape the interrogation room. The specific coercive techniques described were lying about having a witness who identified the suspect in a photo lineup (i.e., false evidence ploy). The selection of this coercive interrogation technique was supported by its frequency and connection to false confession rates (Kassin et al., 2007; Leo \& Ofshe, 1997; Perillo \& Kassin, 2010). The defendant's need to escape was a symptom of a panic attack that 
stemmed from his previous diagnosis of panic disorder (American Psychiatric Association, 2013). The source described why the defendant confessed or almost confessed in the false confession condition. The sources were an expert witness who testified, the defendant who told his lawyer, or both the expert witness and defendant.

False Confession: Present. In the false confession present conditions, during an initial interrogation, the defendant denied committing the crime. During the second interrogation the defendant confessed to having killed his girlfriend.

False Confession: Absent. In the false confession absent conditions, the defendant denied committing the crime during the initial and second interrogations.

Reason: Coercive Interrogation Technique. In the coercive interrogation technique conditions, the interrogator told the defendant that there was an eyewitness that was at the crime scene and had picked him out of a photo line-up as the murderer. However, the witness and therefore photo line-up evidence did not exist.

Reason: Panic-escape. In the need to escape conditions, the suspect had a previous diagnosis of panic disorder and felt a panic attack coming on while in the interrogation room. The panic attack symptoms (e.g., feeling like he is going to have a heart attack) resulted in the suspect's desire to say anything to escape the interrogation room.

Source: Expert Witness Testimony. In the expert witness testimony and coercive interrogation technique conditions, an expert witness testified that in false confession research, coercive interrogation techniques have elicited false confessions. The expert witness additionally testified that the interrogation techniques used were inappropriate. If the expert witness testimony was present in a condition with the presence of panic-escape, the expert witness stated that the interrogation techniques used were appropriate. The expert witness then testified that the suspect 
had a panic disorder diagnosis and described the common symptoms (e.g., feeling like a heart attack is happening). The expert witness continued to testify about the suspect's rationale for wanting to escape (i.e., remove himself from the panic attack environment). Lastly, the expert witness testified that in false confession research, mental health disorders, including anxiety, are a risk factor for false confessions.

Source: Defendant. In conditions when the defendant was the source, he told his attorney during their first meeting why he falsely confessed or almost falsely confessed (i.e., was interrogated with a coercive interrogation technique or was having a panic attack and felt the need to escape). Source: Expert Witness Testimony plus Defendant. The descriptions from the expert witness testimony and defendant sources were both provided.

The 12 conditions were:

False Confession/Coercive Interrogation/Expert Witness (i.e., FC/CI/ExpW)

False Confession/Coercive Interrogation/Expert Witness + Defendant (i.e., FC/CI/ExpW+D)

False Confession, Coercive Interrogation, Defendant (i.e., FC/CI/D)

False Confession, Panic-escape, Expert Witness (i.e., FC/PE/ExpW)

False Confession, Panic-escape, Expert Witness + Defendant (i.e., FC/PE/ExpW+D)

False Confession, Panic-escape, Defendant (i.e., FC/PE/D)

No False Confession, Coercive Interrogation, Expert Witness (i.e., NFC/CI/ExpW)

No False Confession, Coercive Interrogation, Expert Witness + Defendant (i.e., $\mathrm{NFC} / \mathrm{CI} / \operatorname{ExpW+D)}$

No False Confession, Coercive Interrogation, Defendant (i.e., NFC/CI/D)

No False Confession, Panic-escape, Expert Witness (i.e., NFC/PE/ExpW)

No False Confession, Panic-escape, Expert Witness + Defendant (i.e., NFC/PE/ExpW+D) 
No False Confession, Panic-escape, Defendant (i.e., NFC/PE/D)

After reading the trial scenario, participants responded to a series of randomized questions (Krackow \& Longo, 2016; Orcutt, Goodman, Batterman-Faunce, 2001; Tessier \& Krackow, 2013; Krackow, 2020). Questions were rated on a Likert-type scale from 1-10 (i.e., "not at all" to there is "no doubt in my mind"). Participants in all conditions answered questions on their perceptions of the defendant's trustworthiness by answering 1 question (e.g., “trustworthy") and 3 questions regarding guilt (e.g., "guilty?", “committed the act in question", and "responsible for the alleged crime"). Only one indicator of trustworthiness was included in the current study to ensure that the description of trustworthiness applied to the defendant regardless of if he falsely confessed or not. Perceptions of the susceptibility to external influences was asked in 1 question (i.e., “created by the influence of other people?”). Jurors’ perception of their likelihood of changing their mind about their verdict was asked through 2 questions (e.g., "chance of changing their mind" and "likelihood that you would change your verdict"). Relatedly, suggestibility was asked in 1 question (i.e., "suggestible"). An additional dichotomous question regarding defendant guilt was asked.

Attention questions were asked pertaining to the scenario, including 1 to 4 specific questions related to the condition to which the participant was assigned. Participants were then provided an additional 2 unrelated scenarios, followed by 5 questions total to further determine if the study was taken seriously (Krackow, 2018). Demographic questions were then asked. Participants were compensated $\$ 2.00$ through MTurk after completing the study.

\section{RESULTS}

Skew and kurtosis were examined to determine if the data were normally distributed. No outliers were identified, and a normal distribution was supported. The Levene's test of 
homogeneity of variance was run on all outcome variables to determine if the homogeneity of variance assumption was true. Most of the findings were nonsignificant, thereby verifying the assumption. The mean of the jurors' perceived likelihood of changing their verdict indicated a violation $(p=.045)$. However, the median of the jurors' perceived likelihood of changing their verdict did not indicate a violation $(p=.071)$.

\section{Defendant Trustworthiness}

A 2 (false confession: present vs. absent) x 2 (reason: coercive interrogation vs. panicescape) x 3 (source: expert vs. defendant vs. expert plus defendant) ANOVA was run on participants' rating of the defendant's perceived trustworthiness. See Table 1 for ANOVA results. A main effect of False Confession presence was found. Jurors in False Confession present conditions viewed the defendant as less trustworthy than jurors in the No False Confession conditions. See Table 6 for condition cell means, as well as Table 7 and Table 8 for interaction means.

A main effect was not found for Reason; jurors' ratings of the defendant's trustworthiness did not differ between the coercive interrogation and panic-escape conditions. A main effect was also not found for Source; jurors' ratings of the defendant's trustworthiness did not differ based on who (e.g., an expert witness, the defendant, or expert plus defendant) gave the rationale for why the defendant confessed or considered confessing.

The False Confession Presence x Reason interaction was significant. The defendant who did not falsely confess was perceived as less trustworthy only when he felt the need to escape as opposed to when he was interrogated coercively. However, when the defendant did falsely confess, the defendant was perceived as equally trustworthy when interrogated coercively compared to when the defendant was portrayed as feeling the need to escape. 
The False Confession presence x Source interaction was non-significant.

The Reason x Source interaction was significant. Simple main effects analyses showed that there was a main effect of Source in both the Coercive Interrogation condition and in the Panicescape condition. In the Coercive Interrogation condition, there were significant differences per Tukey post-hoc between the Expert Witness only condition and the Expert Witness plus Defendant condition, such that trustworthiness was higher when both the expert witness and defendant were present. A significant difference was also found in the Panic-escape condition between the Expert Witness only condition and the Expert Witness plus Defendant condition. However, trustworthiness was higher when only the expert witness testified rather than when both the expert witness and defendant were present.

The False Confession x Reason x Source interaction effect was non-significant. For expert witness results on defendant trustworthiness please see page 24 .

Defendant Guilt $(\alpha=.955)$

A 2 (confession: present vs. absent) x 2 (reason: coercive interrogation vs. panic-escape) x 3 (source: expert vs. defendant vs. expert plus defendant) ANOVA was run on the participants' mean rating of the three questions of the defendant's perceived guilt. See Table 2 for ANOVA results. A main effect of False Confession presence was found. Jurors in the False Confession present condition viewed the defendant as more guilty than jurors in the False Confession absent conditions. See Table 6 for condition cell means and Table 7 for interaction means.

A main effect of Source was found. A post-hoc Tukey-b analysis with a Bonferroni correction was conducted to further understand the main effect of source. Jurors viewed the defendant as less guilty when the expert witness plus defendant testified than when only the defendant spoke. Jurors also viewed the defendant as less guilty when only the expert witness 
testified than when both an expert witness and the defendant testified. No main effect was found for Reason.

The False Confession x Reason interaction was significant. In the No False Confession condition, when the defendant was interrogated coercively, jurors had a lower perception of guilt than when the defendant felt the need to escape. No such effect was found in the False Confession condition between the defendant who was interrogated coercively and the defendant who felt the need to escape.

The False Confession x Source interaction effect was non-significant, as was the Reason $\mathrm{x}$ Source interaction effect. The False Confession x Reason x Source interaction effect was also non-significant.

Key questions regarding the potential existence of significant differences on the defendant's perceived guilt in False Confession only conditions were not addressed by the above analyses. These questions were addressed by planned contrasts to determine whether there were significant differences between the coercive interrogation and panic-escape reasons for falsely confessing within their respective source (e.g., Expert Witness present condition compared to Expert Witness present condition).

The planned contrast between the false confession/coercive interrogation/expert witness + defendant condition $(M=6.053, S D=2.358)$ and the false confession/panic-escape/expert witness + defendant condition $(M=4.905, S D=2.630)$ showed a marginally significant difference in jurors' perceptions of the defendant's guilt, but with a moderately small effect size of $d=0.48(t(203)=1.963, p=.051)$.

The planned contrast between the false confession/coercive interrogation/expert witness present condition $(M=7.040, S D=2.402)$ and the false confession/panic-escape/expert witness 
present condition $(M=6.478, S D=2.471)$ showed no significant difference in jurors' perceptions of the defendant's guilt $(t(203)=-.055, p=.956, d=-.012)$.

The planned contrast between the false confession/coercive interrogation/defendant present condition $(M=6.398, S D=2.756)$ and the false confession/panic-escape/defendant $(M=6.427$, $S D=2.040$ ) showed no significant difference in jurors' perceptions of the defendant's guilt $(t(203)=1.198, p=.232, d=.240)$.

For expert witness results on defendant guilt please see page 24 .

\section{Defendant Suggestibility}

A 2 (confession: present vs. absent) x 2 (reason: coercive interrogation vs. panic-escape) x 3 (source: expert vs. defendant vs. expert plus defendant) ANOVA was run on the participants' rating of the defendant's perceived suggestibility. See Table 3 for ANOVA results. A main effect of False Confession presence was found. When a false confession was present, the defendant was viewed as more suggestible than when there was no false confession present. The main effect for Reason was non-significant. See Table 6 for condition cell means and Table 7 for interaction means.

A main effect of Source was found. A post-hoc Tukey-b analysis with a Bonferroni correction showed that the presence of expert witness testimony led to higher ratings of suggestibility by jurors. When the defendant or an expert witness plus the defendant explained the reason for the false confession or almost confession, the defendant was perceived as more suggestible than when only the expert witness explained the reason. There were no statistically significant differences between the Defendant only condition and the Expert Witness plus Defendant condition. 
The False Confession presence $\mathrm{x}$ Reason interaction was significant. In the no False Confession condition, jurors viewed the coercively interrogated defendant as less suggestible than the defendant who wanted to escape. There was no statistical difference in the False Confession condition when the defendant was interrogated coercively and when the defendant felt the need to escape.

The False Confession presence x Source interaction was non-significant as was the Reason x Source interaction. The False Confession x Reason x Source interaction effect was also non-significant. For expert witness results on defendant suggestibility please see page 24 .

\section{Defendant Susceptibility to External Influences}

A 2 (reason: coercive interrogation vs. panic-escape) x 3 (source: expert vs. defendant vs. expert plus defendant) ANOVA was run on participants' rating of the defendant's perceived susceptibility to external influences in the false confession conditions only. This analysis is based on 191 participants because the remaining participants did not respond to this question. See Table 4 for ANOVA results. As a reminder, susceptibility to external influences (coercive questioning by the police) only applied to the False Confession Conditions. A main effect of Reason was not found. See Table 6 for condition cell means.

A main effect of Source was found, such that the presence of an expert witness plus the defendant led to higher susceptibility to external influences ratings than when only the expert witness testified about their reason for falsely confessing.

The Reason x Source interaction was non-significant. For expert witness results on defendant susceptibility to external influences please see page 24 .

\section{Likelihood of Changing Verdict}


A 2 (false confession: present vs. absent) x 2 (reason: coercive interrogation vs. panicescape) x 3 (source: expert vs. defendant vs. expert plus defendant) ANOVA was run on participants' mean rating of the likelihood of changing their verdict. See Table 5 for ANOVA results. A main effect of False Confession presence was not found. See Table 6 for condition cell means and Table 7 for interaction means.

A main effect of Reason was found; jurors were more likely to change their verdict if the defendant felt the need to escape compared to if the defendant experienced a coercive interrogation.

A main effect of Source was found. The presence of the defendant only led to jurors being more likely to change their verdict compared to when only the expert witness testified. There were no statistically significant differences between the presence of an expert witness versus both an expert witness plus defendant on jurors' likelihood of changing their verdict. There were no statistically significant differences between the presence of only an expert witness and only the defendant.

The False Confession presence x Reason interaction was significant. More specifically, in the No False Confession conditions, jurors had a higher likelihood of changing their verdict from guilty to not guilty or vice versa when the defendant felt the need to escape than when the defendant was interrogated coercively. In the False Confession Conditions, this effect was nonsignificant, such that the defendant's suggestibility was not different when the defendant felt the need to escape than when he was interrogated coercively.

The False Confession Presence x Source interaction was non-significant as was the Reason $\mathrm{x}$ Source interaction. The False Confession x Reason x Source interaction effect was also non- 
significant. For expert witness results on jurors' likelihood of changing their verdict please see page 24 .

\section{Expert Witness Results}

It is important to determine whether expert witness testimony compared to no expert witness testimony had an impact on the outcome variables. To answer these questions, the two expert witness conditions were combined and a series of $2 \times 2 \times 2$ ANOVAS was conducted. There were main effects of expert witness presence on jurors' perceptions of the defendant's guilt ( $p$ $=.004)$, suggestibility $(p=.051)$, and likelihood of changing verdict $(p=.039)$. Guilt ratings were lower when an expert witness testified $(M=4.841, S E=.136)$ compared to when they did not $(M$ $=5.483, S E=.177)$. Suggestibility ratings were also lower when an expert witness testified $(M=$ $5.264, S E=.136)$ compared to when they did not $(M=6.166, S E=.176)$. Jurors' ratings of the likelihood of changing their verdict were lower with the presence of an expert witness $(M=$ $3.464, S E=.124)$ compared to no expert witness $(M=3.886, S E=.162)$. Ratings of defendant trustworthiness were non-significant $(p=.054)$ when the expert witness was present $(M=5.155$, $S E=.128)$ and absent $(M=5.110, S E=.166)$. Ratings of the defendant's susceptibility to external influences did not differ $(p=.803)$ between expert witness presence $(M=5.765, S E=$ $.227)$ and absence $(M=5.855, S E=.282)$ (based on 414 participants due to 1 participant's failure to answer all questions which was discovered late in the analytic process). The False Confession x Expert Witness, Reason x Expert Witness, and False Confession x Reason x Expert Witness interactions were non-significant.

\section{Discussion}

When the defendant falsely confessed, jurors viewed him as more guilty, as hypothesized, and less trustworthy than when no false confession was given. This finding 
regarding guilt disappeared when the false confession/coercive interrogation conditions were compared to the false confession/panic-escape conditions when the source remained constant. Interestingly, jurors only viewed coercive interrogating as being detrimental in the No False Confession conditions. In the False Confession condition, jurors viewed coercive interrogation to be an equally plausible reason for confession as wanting to escape the interrogation room due to the onset of a panic attack. This last finding held regardless of whether the reason for confession was provide by the defendant themselves or the expert witness, or the defendant plus expert witness.

As expected, jurors also recognized that the defendant was more suggestible when he falsely confessed. However, given that suggestibility to false confession and external influences relate to one another in the false confession conditions, jurors should have also recognized that the defendant who was coercively interrogated (i.e., external influence) was more susceptible to external influences than the defendant who felt the need to escape (i.e., internal influence). It is unknown why there were unable to do so.

Across conditions, jurors were comfortable with their verdict on the defendant's guilt. They were not very likely to change their verdict one way or another. When the defendant did not falsely confess and felt the need to escape, jurors were more open to changing their verdict.

Expert witness testimony regarding false confessions or thoughts of falsely confessing decreased jurors' perceptions of guilt and suggestibility and rendered jurors more likely to change their minds about the verdict. This is consistent with previous findings that the recognition of coercive interrogation techniques increases after an expert witness testifies and therefore guilty verdicts decrease after an expert witness testifies (Blandón-Gitlin, et al., 2009; Woody \& Forrest, 2009). 
Results of analyses with respect to the impact of the three sources on the dependent variables showed no clear pattern. For example, sometimes hearing why the defendant confessed/almost confessed seemed to have a negative impact on jurors' ratings. Future research should continue to examine this issue to gain a better picture of these findings.

\section{Limitations}

One limitation of this study was the use of Amazon Mechanical Turk to recruit participants. Participants were recruited online and completed the study without any in-person interactions. The lack of in-person contact sets the current study apart from criminal trials as they typically occur. Therefore, the results obtained may not generalize to in person criminal trials. Participants acted as mock jurors but did so online and without deliberating with other mock jurors. Also, participants predominantly identified their race as Caucasian. It is unknown whether these results would generalize to different racial or ethnic populations, given possible differences with police experiences.

The present study's purpose was to learn about mock jurors' perceptions of false confessions. The trial scenarios consistently described the defendant as a 25 -year-old male. As a result, the findings may not generalize to defendants of different ages and genders. The defendant's race was not included in the trial scenarios to prevent this information from influencing the results.

A true confession was not included because the study focused on false confessions. Furthermore, additional conditions would have increased the complexity of the current study. Nonetheless, true confession conditions can be beneficial comparison groups. 
The avenues differed by which the defendant and expert witness (i.e., source) used to inform the jury of why a false confession was likely, which may be a limitation. In the trial scenarios, the defendant told his lawyer why he falsely confessed or considered falsely confessing (e.g., coercive interrogation). The lawyer then told this information to the jury. However, the expert witness testified in front of the jury as to why the defendant likely confessed or considered confessing. These means differed to best represent what occurs in a criminal trial. Defendants rarely take the stand when on trial for murder (Bellin, 2018). Finally, the current manuscript only includes results from continuous measurements of guilt, despite categorical data also being collected. This information is not included because the logistic regression analysis would not run properly.

\section{Future Directions}

Studies in the future should aim to decrease the limitations presented. For instance, this study may be replicated in a real courtroom and/or with jurors who deliberate with one another. These changes will make the study more realistic. The defendant's characteristics, such as age, race, and gender should also be varied to increase the generalizability. The present study used false evidence as a coercive interrogation technique. Future studies should include different coercive interrogation techniques or a combination of techniques. The inclusion of other techniques will increase the understanding of jurors' perceptions of false confessions when a defendant has been interrogated coercively.

\section{Conclusion}

The results of the current study suggest that jurors are more likely to believe that someone who falsely confessed is guilty, possibly because jurors in the current study did not understand why the defendant falsely confessed. Expert witness testimony was helpful in 
reducing guilt ratings regardless of whether the defendant falsely confessed or almost falsely confessed but decided against doing so. Jurors did not view the defendant as more guilty if the reason for false confession was coercive interrogation or wanting to escape the interrogation room due to the onset of a panic attack. 


\section{References}

American Psychiatric Association. (2013). Diagnostic and statistical manual of mental disorders : dsm-5 (5th ed.). American Psychiatric Association.

Bellin, J. (2018). The silence penalty. Iowa Law Review, 103, 395-434.

Blandón-Gitlin, I., Sperry, K., \& Leo, R. A. (2011). Jurors believe interrogation tactics are not likely to elicit false confessions: Will expert witness testimony inform them otherwise? Psychology, Crime \& Law, 17, 239-260.

Bottoms, B. L., \& Goodman, G. S. (1994). Perceptions of children's credibility in sexual assault cases. Journal of Applied Social Psychology, 24(8), 702-732.

Conti, R. (1999). The psychology of false confessions. Journal of Credibility Assessment and Witness Psychology, 2, 14-36.

Costanzo M, Shaked-Schroer N, Vinson K, (2010). Juror beliefs about police interrogations, false confessions, and expert testimony. Journal of Empirical Legal Studies 7(2):231247.

Cowley, M., \& Colyer, J. (2010). Asymmetries in prior conviction reasoning: Truth suppression effects in child protection contexts. Psychology, Crime \& Law, 16(3), 211-231.

Decker, S., Ortiz, N., Spohn, C., \& Hedberg, E. (2015). Criminal stigma, race, and ethnicity: The consequences of imprisonment for employment. Journal of Criminal Justice, 43(2), 108121.

Drizin, S. A., \& Leo, R. A. (2004). The problem of false confessions in the post-DNA world. North Carolina Law Review, 82, 891-1007. 
Frenda, S. J., Berkowitz, S. R., Loftus, E. F., \& Fenn, K. M. (2016). Sleep deprivation and false confessions. PNAS: Proceedings of the National Academy of Sciences of the United States of America, 113, 2047-2050.

Greene, E., \& Dodge, M. (1995). The influence of prior record evidence on juror decisionmaking. Law and Human Behavior, 19, 67-78.

Goodman, G. S., Golding, J. M., \& Haith, M. M. (1984). Jurors' reactions to child witnesses. Journal of Social Issues, 40(2), 139-156.

Henkel, L. A., Coffman, K. A. J., \& Dailey, E. M. (2008). A survey of people's attitudes and beliefs about false confessions. Behavioral Sciences \& the Law, 26, 555-584.

Honts, C.R., Kassin, S. M., \& Craig, R. A. (2014). 'I'd know a false confession if I saw one': a constructive replication with juveniles. Psychology, Crime \& Law, 20(7), 695-704

Kassin, S. M. (2010). False confessions. Albany Law Review, 73(4), 1227-1234.

Kassin, S. M., Drizin, S. A., Grisso, T., Gudjonsson, G. H., Leo, R. A., \& Redlich, A. D. (2010). Police-induced confessions: Risk factors and recommendations. Law and Human Behavior, 34, 3-38.

Kassin, S. M., \& Kiechel, K. L. (1996). The social psychology of false confessions: Compliance, internalization, and confabulation. Psychological Science, 7, 125-128.

Kassin, S. M., Leo, R.A., Meissner, C.A., Richman, K.D., Colwell, L.H., Leach, A., \& La Fon, D. (2007). Police Interviewing and Interrogation: A Self-Report Survey of Police Practices and Beliefs. Law Human Behavior 31, 381-400.

Kassin, S. M., Meissner, C. A., \& Norwick, R. J. (in press). "I'd know a false confession if I saw one": A comparative study of college students and police investigators. Law and Human Behavior. 
Kassin, S. M., \& Sukel, H. (1997). Coerced confessions and the jury: An experimental test of the "harmless error" rule. Law and Human Behavior, 21, 27-46.

Klaver, J. R., Lee, Z., \& Rose, V. G. (2008). Effects of personality, interrogation techniques and plausibility in an experimental false confession paradigm. Legal \& Criminological Psychology, 13(1), 71-88.

Krackow, E. (2018). Effects of autism spectrum disorder diagnosis, coaching, and accuracy of autobiographical factual recall on jurors' perceptions of child witnesses. Poster presented at the American Psychology-Law Society Meetings, Memphis.

Krackow, E. (2020). Supplemental materials.

Krackow, E., \& Longo, A. (2016). Effects of memory recovery technique on jurors' perceptions of recovered memories. International Journal of Psychological Studies.

Levine, T. R., Kim, R. K., \& Blair, J. P. (2010). (In)accuracy at detecting true and false confessions and denials: An initial test of a projected motive model of veracity judgments. Human Communication Research, 36, 81-101.

Leo, R. A. \& Ofshe, R. J. (1997). Consequences of false confessions: Deprivations of liberty and miscarriages of justice in the age of psychological interrogation. Journal of Criminal Law \& Criminology, 88, 429.

Lynch, M. (2008). Truth machine: the contentious history of dna fingerprinting. University of Chicago Press.

Lynch, K. R., Wasarhaley, N. E., Golding, J. M. \& Simcic, T. A. (2013). Who bought the drinks? Juror perceptions of intoxication in a rape trial. Journal of Interpersonal Violence, 28, $3205-3222$. 
Narchet, F. M., Meissner, C. A., \& Russano, M. B. (2011). Modeling the influence of investigator bias on the elicitation of true and false confessions. Law and Human Behavior, 35, 452-465.

Orcutt, H. K., Goodman, G. S., Tobey, A. E., Batterman-Faunce, J. M., \& Thomas, S. (2001). Detecting deception in children's testimony: Factfinders' abilities to reach the truth in open court and closed-circuit trials. Law and Human Behavior, 25(4), 339-372.

Perillo, J. T., \& Kassin, S. M. (2011). Inside interrogation: The lie, the bluff, and false confessions. Law and Human Behavior, 35, 327-337.

Russano, M. B., Miessner, C. A., Narchet, F. M., \& Kassin, S. M. (2005). Investigating true and false confessions within a novel experimental paradigm. Psychological Science, 16, 481486.

Shifton, J. J. (2019). How confession characteristics impact juror perceptions of evidence in criminal trials. Behavioral Sciences \& the Law, 37, 90-108.

Tessier, P., \& Krackow, E. (2013). The effects of interviewing technique and research evidence on jurors' perceptions of child witnesses. Poster presented at the American PsychologyLaw Society meetings.

West, E., \& Meterko, V. (2016). Innocence Project: DNA exonerations, 1989-2014; Review of data and findings from the first 25 years. Albany Law Review, 79, 717-795.

Wissler, R. L., \& Saks, M. J. (1985). On the inefficacy of limiting instructions. Law and Human Behavior, 9, 37-48.

Woestehoff, S. A., \& Meissner, C. A. (2016). Juror sensitivity to false confession risk factors: Dispositional vs. situational attributions for a confession. Law and Human Behavior, 40, 564-579. 
Woody, W. D., \& Forrest, K. D. (2009). Effects of false-evidence ploys and expert testimony on jurors' verdicts, recommended sentences, and perceptions of confession evidence. Behavioral Sciences and the Law, 27, 333-360. 
Table 1

Means, Standard Errors, and Univariate Analyses of Variance for Defendant Trustworthiness

\begin{tabular}{|c|c|c|c|c|c|c|}
\hline & $M$ & $\mathrm{SE}$ & df & $\mathrm{F}$ & P-value & $\eta_{p}^{2}$ \\
\hline False Confession & & & 1,404 & 51.813 & $.000 * * *$ & .114 \\
\hline Present & $4.683_{\mathrm{a}}$ & .141 & & & & \\
\hline Absent & $6.130_{\mathrm{b}}$ & .143 & & & & \\
\hline Reason & & & 1,404 & 1.054 & .305 & .003 \\
\hline Coercive Interviewing & 5.510 & .137 & & & & \\
\hline Panic-escape & 5.304 & .147 & & & & \\
\hline Source & & & 2,404 & 2.968 & .053 & .015 \\
\hline Expert + Defendant & $5.655_{\mathrm{a}}$ & .179 & & & & \\
\hline Expert & $5.480_{\mathrm{a}}$ & .162 & & & & \\
\hline Defendant & $5.086 \mathrm{~b}$ & .180 & & & & \\
\hline False Confession $\mathrm{x}$ Reason & & & 1,404 & 8.761 & $.003 * *$ & .021 \\
\hline False Confession x Source & & & 2,404 & .048 & .953 & .000 \\
\hline Reason x Source & & & 2,404 & 5.584 & $.004 * *$ & .027 \\
\hline $\begin{array}{l}\text { False Confession x Reason } \\
\text { x Source }\end{array}$ & & & 2,404 & 1.885 & .153 & .009 \\
\hline
\end{tabular}

$* p<.05 . * * p<.01 . * * * p<.001$.

Means with differing subscripts are significantly different 
Table 2

Means, Standard Errors, and Univariate Analyses of Variance for Defendant Guilt

\begin{tabular}{|c|c|c|c|c|c|c|}
\hline & $M$ & $\mathrm{SE}$ & df & $\mathrm{F}$ & P-value & $\eta_{p}^{2}$ \\
\hline False Confession & & & 1,404 & 119.572 & $.000 * * *$ & .229 \\
\hline Present & $6.214_{a}$ & .149 & & & & \\
\hline Absent & $3.890_{\mathrm{b}}$ & .151 & & & & \\
\hline Reason & & & 1,404 & .043 & .837 & .000 \\
\hline Coercive Interviewing & 5.030 & .144 & & & & \\
\hline Panic-escape & 5.074 & .156 & & & & \\
\hline Source & & & 2,404 & 12.785 & $.000 * * *$ & .060 \\
\hline Expert + Defendant & $4.290_{\mathrm{a}}$ & .190 & & & & \\
\hline Expert & $5.372_{b}$ & .190 & & & & \\
\hline Defendant & $5.495 \mathrm{~b}$ & .172 & & & & \\
\hline False Confession x Reason & & & 1,404 & 8.224 & $.004^{* *}$ & .020 \\
\hline False Confession x Source & & & 2,404 & 1.657 & .192 & .008 \\
\hline Reason x Source & & & 2,404 & .246 & .782 & .001 \\
\hline $\begin{array}{l}\text { False Confession x Reason } \\
\text { x Source }\end{array}$ & & & 2,404 & 1.305 & .272 & .006 \\
\hline
\end{tabular}

$* p<.05 . * * p<.01 . * * * p<.001$.

Means with differing subscripts are significantly different 
Table 3

Means, Standard Errors, and Univariate Analyses of Variance for Defendant Suggestibility

\begin{tabular}{l|c|c|c|c|c|c}
\hline & $M$ & SE & df & F & P-value & $\eta_{\mathrm{p}}{ }^{2}$ \\
\hline False Confession & & & 1,404 & 14.517 & $.000^{* * *}$ & .035 \\
Present & $6.218_{\mathrm{a}}$ & .150 & & & \\
Absent & $5.402_{\mathrm{b}}$ & .153 & & & \\
Reason & & & 1,404 & 3.446 & .064 & .008 \\
Coercive Interviewing & 5.611 & .146 & & & \\
Panic-escape & 6.009 & .157 & & & \\
Source & & & 2,404 & 8.861 & $.000 * * *$ & .042 \\
Expert + Defendant & $6.099_{\mathrm{a}}$ & .191 & & & & \\
Expert & $5.166_{\mathrm{b}}$ & .192 & & & & \\
Defendant & $6.165_{\mathrm{a}}$ & .173 & & & & \\
False Confession x Reason & & & 1,404 & 10.340 & $.001 * * *$ & .020 \\
False Confession x Source & & & 2,404 & 2.249 & .107 & .011 \\
Reason x Source & & & 2,404 & .246 & .676 & .002 \\
False Confession x Reason & & & 2,404 & .266 & .767 & .001 \\
x Source & & & & & \\
\hline
\end{tabular}

$* p<.05 . * * p<.01 . * * * p<.001$.

Means with differing subscripts are significantly different 
Table 4

Means, Standard Errors, and Univariate Analyses of Variance for Defendant Susceptibility of External Influences

\begin{tabular}{l|c|c|c|c|c|c}
\hline & $M$ & $\mathrm{SE}$ & $\mathrm{df}$ & $\mathrm{F}$ & $\mathrm{P}$-value & $\eta_{\mathrm{p}}{ }^{2}$ \\
\hline Reason & & & 1,192 & .682 & .410 & .004 \\
$\quad$ Coercive Interviewing & 5.948 & .243 & & & & \\
$\quad$ Panic-escape & 5.658 & .253 & & & & \\
Source & & & 2,192 & 3.447 & $.034^{*}$ & .036 \\
Expert + Defendant & $6.413 \mathrm{a}$ & .325 & & & & \\
Expert & $5.22 \mathrm{~b}_{\mathrm{b}}$ & .310 & & & & \\
$\quad$ Defendant & 5.762 & .274 & & & & \\
Reason x Source & & & 2,192 & .611 & .517 & .007 \\
\hline
\end{tabular}

$* p<.05 . * * p<.01 . * * * p<.001$.

Means with differing subscripts are significantly different 
Table 5

Means, Standard Errors, and Univariate Analyses of Variance for Jurors' Likelihood of Changing Their Verdict on Guilt

\begin{tabular}{|c|c|c|c|c|c|c|}
\hline & $M$ & $\mathrm{SE}$ & $\mathrm{df}$ & $\mathrm{F}$ & P-value & $\eta_{p}^{2}$ \\
\hline False Confession & & & 1,404 & 3.052 & .081 & .008 \\
\hline Present & 3.779 & .139 & & & & \\
\hline Absent & 3.432 & .142 & & & & \\
\hline Reason & & & 1,404 & 4.072 & $.044^{*}$ & .010 \\
\hline Coercive Interviewing & $3.405_{\mathrm{a}}$ & .134 & & & & \\
\hline Panic-escape & $3.805 \mathrm{~b}$ & .146 & & & & \\
\hline Source & & & 2,404 & 3.155 & $.044 *$ & .015 \\
\hline Expert + Defendant & 3.553 & .178 & & & & \\
\hline Expert & $3.338 \mathrm{a}$ & .177 & & & & \\
\hline Defendant & $3.925 \mathrm{~b}$ & .160 & & & & \\
\hline False Confession $\mathrm{x}$ Reason & & & 1,404 & 5.048 & $.025 *$ & .012 \\
\hline $\begin{array}{l}\text { False Confession } \mathrm{x} \\
\text { Source }\end{array}$ & & & 2,404 & .988 & .373 & .005 \\
\hline Reason x Source & & & 2,404 & .868 & .421 & .004 \\
\hline $\begin{array}{l}\text { False Confession x Reason } \\
\text { x Source }\end{array}$ & & & 2,404 & .341 & .711 & .002 \\
\hline
\end{tabular}

$* p<.05 . * * p<.01 . * * * p<.001$.

Means with differing subscripts are significantly different 
Table 6

Means and Standard Deviations for all Outcome Variables

\begin{tabular}{|c|c|c|c|c|c|c|c|c|c|c|c|c|}
\hline & \multicolumn{2}{|c|}{$\begin{array}{c}(n=38) \\
(n=30)^{*} \\
\mathrm{FC} / \mathrm{CI} / \operatorname{Exp} \mathrm{W}+\mathrm{D}\end{array}$} & \multicolumn{2}{|c|}{$\begin{array}{l}(n=41) \\
(n=39)^{*} \\
\text { FC/CI/D }\end{array}$} & \multicolumn{2}{|c|}{$\begin{array}{c}(n=33) \\
(n=30)^{*} \\
\text { FC/CI/ExpW }\end{array}$} & \multicolumn{2}{|c|}{$\begin{array}{c}(n=28) \\
(n=25)^{*} \\
\text { FC/P/ExpW+D }\end{array}$} & \multicolumn{2}{|c|}{$\begin{array}{c}(n=39) \\
(n=38)^{*} \\
\mathrm{FC} / \mathrm{P} / \mathrm{D}\end{array}$} & \multicolumn{2}{|c|}{$\begin{array}{c}\quad(n=30) \\
(n=29)^{*} \\
\text { FC/P/ExpW }\end{array}$} \\
\hline & $M$ & SD & $M$ & $\mathrm{SD}$ & $M$ & $\mathrm{SD}$ & $M$ & $\mathrm{SD}$ & $M$ & SD & $M$ & SD \\
\hline Guilt & 6.053 & 2.358 & 6.398 & 2.276 & 7.040 & 2.401 & 4.905 & 2.629 & 6.427 & 2.040 & 6.468 & 2.741 \\
\hline Trustworthiness & 4.080 & 2.045 & 4.150 & 2.116 & 5.240 & 2.332 & 5.710 & 2.447 & 4.560 & 2.150 & 4.330 & 1.882 \\
\hline Suggestibility & 6.660 & 2.134 & 6.460 & 2.357 & 5.970 & 2.494 & 6.790 & 2.114 & 6.080 & 1.628 & 5.230 & 1.977 \\
\hline Susceptibility to & 6.267 & 2.612 & 6.077 & 2.454 & 5.500 & 2.688 & 6.560 & 2.678 & 5.447 & 1.672 & 5.035 & 2.383 \\
\hline \multicolumn{13}{|l|}{ External Influences* } \\
\hline Likelihood of Changing & 3.961 & 2.015 & 4.110 & 2.981 & 3.333 & 1.685 & 3.893 & 2.485 & 3.923 & 2.181 & 3.367 & 1.925 \\
\hline \multicolumn{13}{|l|}{ Verdict } \\
\hline & \multicolumn{2}{|c|}{$\begin{array}{c}(n=40) \\
\mathrm{NFC} / \mathrm{CI} / \operatorname{ExpW}+\mathrm{D}\end{array}$} & \multicolumn{2}{|c|}{$\begin{array}{c}(n=41) \\
\text { NFC/CI/D }\end{array}$} & \multicolumn{2}{|c|}{$\begin{array}{c}(n=30) \\
\text { NFC/CI/ExpW }\end{array}$} & \multicolumn{2}{|c|}{$\begin{array}{c}(n=26) \\
(n=25)^{* *} \\
\text { NFC/P/ExpW+D }\end{array}$} & \multicolumn{2}{|c|}{$\begin{array}{c}(n=35) \\
\mathrm{NFC} / \mathrm{P} / \mathrm{D}\end{array}$} & \multicolumn{2}{|c|}{$\begin{array}{c}(n=33) \\
\text { NFC/P/ExpW }\end{array}$} \\
\hline & $M$ & SD & $M$ & SD & $M$ & SD & $M$ & $\mathrm{SD}$ & $M$ & $\mathrm{SD}$ & $M$ & SD \\
\hline Guilt & 2.675 & 1.564 & 4.382 & 1.802 & 3.633 & 2.166 & 3.525 & 1.784 & 4.771 & 1.936 & 4.353 & 2.234 \\
\hline Trustworthiness & 6.750 & 1.676 & 5.980 & 1.695 & 6.870 & 1.833 & 6.080 & 1.573 & 5.660 & 2.326 & 5.450 & 2.063 \\
\hline Suggestibility & 4.880 & 2.015 & 5.630 & 1.959 & 4.070 & 2.638 & 6.080 & 1.853 & 6.490 & 2.188 & 5.270 & 2.349 \\
\hline Susceptibility to & - & - & - & - & - & - & - & - & - & - & - & - \\
\hline External Influences & & & & & & & & & & & & \\
\hline Likelihood of Changing & 2.600 & 1.846 & 3.695 & 1.955 & 2.733 & 1.799 & 3.760 & 1.763 & 3.971 & 2.156 & 3.833 & 1.195 \\
\hline Verdict** & & & & & & & & & & & & \\
\hline
\end{tabular}


Table 7

Means and Standard Deviations for False Confession x Reason Interaction

\begin{tabular}{l|c|c|c|c|c|c|c|c}
\hline & \multicolumn{2}{|c|}{$\begin{array}{c}\text { False Confession } \\
\text { x Coercion }\end{array}$} & \multicolumn{2}{c|}{$\begin{array}{c}\text { False Confession x } \\
\text { Panic-escape }\end{array}$} & \multicolumn{2}{c}{$\begin{array}{c}\text { No False Confession } \\
\text { x Coercion }\end{array}$} & \multicolumn{2}{c}{$\begin{array}{c}\text { No False Confession } \\
\text { x Panic-escape }\end{array}$} \\
& $M$ & SE & $M$ & SE & $M$ & SE & $M$ & SE \\
\hline Guilt & 6.470 & .225 & 6.003 & .241 & 3.565 & .190 & 4.280 & .206 \\
Trustworthiness & 4.446 & .208 & 4.827 & .223 & 6.495 & .180 & 5.702 & .195 \\
Suggestibility & 6.384 & .205 & 6.051 & .219 & 4.937 & .211 & 5.947 & .230 \\
Likelihood of & 3.830 & .200 & 3.765 & .214 & 3.041 & .178 & 3.866 & .195 \\
Changing Verdict & & & & & & & &
\end{tabular}

Note: Only variables with significant findings are included in this table. 
Table 8

Means and Standard Deviations for Reason x Source Interaction

\begin{tabular}{|c|c|c|c|c|c|c|c|c|c|c|c|c|}
\hline & \multicolumn{2}{|c|}{$\begin{array}{c}\text { Coercive Interview } \\
\text { x Expert }+ \\
\text { Defendant }\end{array}$} & \multicolumn{2}{|c|}{$\begin{array}{c}\text { Coercive } \\
\text { Interview } \\
\text { x Defendant }\end{array}$} & \multicolumn{2}{|c|}{$\begin{array}{c}\text { Coercive } \\
\text { Interview x } \\
\text { Expert }\end{array}$} & \multicolumn{2}{|c|}{$\begin{array}{c}\text { Panic-escape } \\
\text { x Expert }+ \\
\text { Defendant }\end{array}$} & \multicolumn{2}{|c|}{$\begin{array}{l}\text { Panic-escape } \\
\text { x Defendant }\end{array}$} & \multicolumn{2}{|c|}{$\begin{array}{c}\text { Panic-escape } \\
\text { x Expert }\end{array}$} \\
\hline & $M$ & $\mathrm{SE}$ & $M$ & $\mathrm{SE}$ & $M$ & SE & $M$ & SE & $M$ & SE & $M$ & $\mathrm{SE}$ \\
\hline Trustworthiness & 5.449 & .251 & 6.016 & .279 & 5.061 & .245 & 5.889 & .291 & 4.922 & .267 & 5.081 & .249 \\
\hline
\end{tabular}

Note: Only variables with significant findings are included in this table. 